\title{
DEMANDAS EMERGENTES EM EDUCAÇÃO: AS POLÍTICAS DE COMBATE AO RACISMO ${ }^{1}$
}

\author{
SANTOS, Renato Emerson dos $^{2}$
}

\begin{abstract}
RESUMO:
Nas duas últimas décadas vem emergindo na educação brasileira um conjunto de iniciativas de combate ao racismo. Legislações, políticas públicas, ativismos sociais, entre outras, vem materializando e ao mesmo tempo impulsionando um conjunto bastante diversificado de agendas. $\mathrm{O}$ protagonismo central neste processo é do Movimento Negro Brasileiro, que historicamente toma o campo da educação como um instrumento privilegiado de combate ao racismo na sociedade, e que vem conseguindo então produzir ecos institucionais de suas lutas, posicionando-se como importante ator social que disputa o currículo, em suas múltiplas dimensões. O presente artigo aborda algumas das principais frentes/agendas deste campo, como a reserva de vagas e os cursos pré-vestibulares como formas de acesso ao ensino superior, e a Lei 10.639 na educação básica. Parte-se da compreensão do racismo como um sistema de dominação social para compreender a importância da disputa no campo da educação como estratégia da luta anti-racismo.
\end{abstract}

PalAVRas-Chave: Educação das relações raciais - Movimento Negro e educação - Lei 10.639 Reserva de vagas no ensino superior - Pré-vestibulares para negros e carentes.

\begin{abstract}
:
A set of initiatives to fight racism has emerged in Brazilian education in the last two decades. There have been Laws, public policies, social activism, among others that have been triggering different agendas. The Brazilian Black Movement, which historically considers the educational area as an important instrument to fight racisme in society, has a central role in the process. The movement has managed to echo their fights institutionally, condolidating their position as an important social actor that disputes curriculum in its multiple dimensions. The present article approaches some of the main fronts and agendas in this field, such as social quotas and preuniversity courses that function as ways to promote access to higher education as well as the Law 10.639 in basic education. Racism is viewed as a system of social domination so that the
\end{abstract}

\footnotetext{
1 Texto elaborado a partir de palestra realizada no VIII Simpósio Educação e Sociedade Contemporânea / 2013 CAp-UERJ, no dia 17 de outubro de 2013.

2 Professor do Departamento de Geografia da Faculdade de Formação de Professores da UERJ. Renato emerson@yahoo.com.br
} 
importance of the dispute in the educational field is understood as a strategie in combating racism.

KEYWORDS: Racial relations education - Black Movement and education - Law 10.639 - Quotas for higher education - Pre-university courses for black and poor people.

O campo da educação vem sendo, recentemente, objeto cada vez maior de disputa por segmentos sociais historicamente desfavorecidos. Diversos movimentos e lutas sociais, organizados ou não, vêm compreendendo a importância da formação humana como estratégia de fortalecimento de suas lutas, e se voltando para disputas no campo educacional. Um exemplo disso é o que vem sendo feito pelo Movimento Negro Brasileiro, em sua luta antirracismo.

O presente texto busca abordar algumas das frentes de luta do Movimento Negro no campo da educação no Brasil. Não temos aqui a pretensão de esgotamento do tema, diante da pluralidade de agendas que este movimento vem construindo no campo da educação: superação do racismo nos ambientes escolares, transformações curriculares de combate ao eurocentrismo dos conhecimentos escolares, produção de conhecimento, produção e difusão de materiais didáticos e de apoio, formação (inicial e continuada) de profissionais da educação para o tratamento das questões raciais, entre outras, são apenas algumas das agendas abertas pelo movimento social atualmente.

\section{COTAS E PRÉ-VESTIBULARES}

Começamos este breve tour por algumas das lutas e agendas de combate ao racismo no campo da Educação, construídas pelo Movimento Negro, por uma iniciativa da qual participamos, desde os anos 1990. Era o Pré-Vestibular para Negros e Carentes, que inclusive tem um papel fundamen- tal na caminhada que nos leva a estar hoje, discutindo políticas de acesso e permanência de populações menos favorecidas no ensino superior ${ }^{3}$.

Essa iniciativa foi, nos anos 90, talvez o movimento social que mais cresceu no espaço urbano brasileiro. As formas de ação coletiva, as formas reivindicativas de ação política coletiva no espaço urbano no Brasil, tiveram um período de enfraquecimento bastante forte. Nos anos de 1990, o movimento social que mais cresceu foi o MST, no espaço agrário. Outros movimentos, como os sindicais e outras formas coletivas de ação social urbanas enfrentaram um período de enfraquecimento e, ao mesmo tempo, o Pré-Vestibular para Negros e Carentes conseguiu se fortalecer.

O primeiro núcleo foi criado em 1993, em São João de Meriti, pelo Frei Davi e mais um grupo de militantes. E em pouco tempo, em 1995 e 1996, já eram mais de 80 núcleos de pré-vestibular espalhados pela Região Metropolitana do Rio de Janeiro. Cursos de pré-vestibulares na Baixada, no Rio e em Niterói. Mais de 80 cursos conduzindo fortemente, por meio da iniciativa de capacitação de pessoas para fazerem os exames vestibulares, uma pauta que era bastante plural.

\footnotetext{
${ }^{3}$ Referência às experiências do autor como professor de Geografia nos núcleos de Pré-Vestibular para Negros e Carentes da Rocinha (de 1996 a 2002) e Tijuca (em 1998 e 2000), e no pré-vestibular comunitário do CEASM, Centro de Estudos e Ações Solidárias da Maré (em 1999). No Pré Rocinha, foi também coordenador e professor da disciplina Cultura e Cidadania.
} 
A ideia dos militantes que construíram o pré-vestibular era de não apenas formar esses alunos para passar no vestibular e entrar na Universidade, mas se constituir numa iniciativa que tensionava primeiro, as desigualdades raciais existentes na sociedade brasileira e, em específico, as desigualdades raciais no ensino superior. Os números que os militantes dispunham naquela época apontavam que apenas $6 \%$ de estudantes nas universidades do Brasil eram negros, em um período em que a população negra, segundo números do IBGE, beirava os $50 \%{ }^{4}$. Então se apontava um fato, um dado, um dado grave, de desigualdade racial no acesso ao ensino superior. Uma desproporção entre a participação negra na sociedade brasileira e a participação dela dentro das instituições de ensino superior.

Ao mesmo tempo também se questionava - estamos tratando de um cenário no início dos anos 1990 - o grave quadro da educação, sobretudo na Baixada Fluminense, que foi onde nasceu esse movimento de Pré-Vestibular para Negros e Carentes. Reclamava-se muito da falta de uma oferta de escolas - não apenas da dimensão qualitativa das escolas, mas muitos estudantes terminavam o que hoje é o ensino fundamental (na época, $1^{\circ} \mathrm{grau}$ ) e não tinham escolas de $2^{\circ}$ grau (atual ensino médio) para cursar. Faltava oferta de aparelhos educacionais.

Então, o movimento nasce pautando nessas duas questões. Dizíamos: "não queremos apenas formar pessoas para entrar na Universidade, nós queremos que as pessoas entrem na Universidade críticas, com uma postura crítica em relação ao contexto social que as gera e que gera a nossa própria ação. Então nós queremos que nossos alunos entrem na universidade com uma

\footnotetext{
${ }^{4}$ Não buscamos aqui checar tais números, pois o que nos importa era seu uso político pela militância no Movimento Social.
}

nitidez social da sua posição, da sua condição e que eles venham, no futuro, a utilizar o seu saber não apenas para terem acesso a um posto de trabalho bem remunerado, mas que eles usem esse conhecimento para fortalecer a iniciativa de transformação social".

Portanto, era também uma crítica ao tipo de ensino e formação que as Universidades ofereciam, muitas centradas numa formação profissional para a colocação no mercado de trabalho, sem debater mais profundamente a natureza social do conhecimento e do saber que a Universidade produzia.

O outro pilar de crítica que alicerçava aquela iniciativa era exatamente combater a produção social de desigualdades feita através dos aparatos de escolarização. Era uma crítica muito forte à escola pública como lugar, como instrumento de produção e reprodução de desigualdades. Evidentemente, se nós a apontávamos como (re)produtora de desigualdade, apontávamos também a escola como espaço possível para transformação. Então, disputávamos a escola, por acreditar que ela tinha um papel potencial fundamental na transformação desse quadro de desigualdade social e de desigualdade racial que observávamos naquele momento.

O pré-vestibular teve uma repercussão social muito importante naquele contexto, pois através dele muitas iniciativas foram realizadas naquela época. $O$ tensionamento da e na Universidade era muito forte, pelas diversas formas com que a Universidade excluía estudantes pobres e negros do acesso a ela mesma. Então, a primeira iniciativa foi dialogar com as universidades públicas para que elas dessem a isenção do pagamento da taxa de inscrição do vestibular. Era uma maneira de provocar um "olha, isso aqui você tá cobrando, essa cobrança tem 
um impacto social desigual, ela acaba operando como mecanismo de exclusão de alunos pobres à própria universidade". A UERJ, inclusive, ao ser objeto desse tensionamento teve uma politica muito forte, muito importante no movimento ao isentar os alunos que eram formados nesses cursos de pagar as taxas de inscrição.

Uma série de ações de mais impacto midiático, tais como alunos se acorrentando na Universidade, nas grades da UERJ, aconteceram. Coisas que tiveram impactos políticos muito fortes, que cacifaram o movimento naquele momento para dialogar com as esferas do Estado - não só prefeituras municipais, mas governos de estaduais e do governo federal, visando pensar formas de democratizar o acesso ao ensino superior. Essa pauta, e é importante lembrar que nós estamos hoje debatendo esses temas por conta dessa iniciativa de militância social, foi o movimento de Pré-Vestibulares para $\mathrm{Ne}$ gros e Carentes que trouxe à agenda. Movimento que tem esse braço de nascedouro muito forte no Rio de Janeiro, mas que se espraiou por todo o Brasil, se aliou com outras iniciativas que surgiram concomitantemente a ele, em outros lugares do Brasil (como na Bahia, através da Cooperativa Steve Biko em Salvador), e colocou na agenda pública no começo da década passada a necessidade de políticas de democratização no acesso ao ensino superior.

Esses movimentos pautaram fortemente isso no governo federal, no contexto de preparação da delegação brasileira para a Conferência de Durban, a Conferência Mundial Contra o Racismo, em 2001. E é nesse contexto de preparação da delegação brasileira para Durban, que vão surgir as duas primeiras iniciativas que definem as cotas, as reservas de partes das vagas de universidades estaduais para estudantes negros e estudantes com o perfil sócio- econômico desfavorecido. As iniciativas, tanto na Bahia, na UNEB, quanto no Rio de Janeiro - UERJ e UENF - que começaram a implementar essas politicas em 2003, foram decididas, ainda no final de 2001, no contexto da Conferência de Durban. A Lei aqui no Rio de Janeiro é bem do finalzinho do ano, lá na Bahia a decisão do conselho universitário também. Nesse contexto de tensionamento do Movimento Negro, houve toda uma necessidade de tomada de posição por parte de esferas do Estado brasileiro sobre essa temática.

Portanto, se hoje discutimos isso, é porque uma série de outras politicas se desdobrou a partir de então. Logo depois, em 2003, diversas universidades federais começaram a tomar decisões através dos seus conselhos universitários para implementar políticas semelhantes. No final de 2003, eram sete universidades já com políticas para começarem no ano de 2004, outras começando em 2005. A UnB, por exemplo, definiu em junho de 2003, mas começou a implementar no vestibular para ingresso em 2005. Enfim, começa uma onda de Universidades adotando essas políticas, até que recentemente, em 2012, foi promulgada uma Lei que define cotas para universidades e institutos federais.

Evidentemente, a pauta se pluraliza, outras coisas vão acontecer. A Fundação Ford, na época também em 2001, resolveu dar um apoio financeiro às iniciativas desse tipo, pensando inicialmente não nas Universidades (ainda não havia a política de cotas), mas voltando-se para os cursos prévestibulares. Dessa iniciativa da Fundação Ford, que foi sediada pela UERJ, no seu Laboratório de Políticas Públicas, nasceu o Programa de Políticas da Cor. A partir de 2003, ele apoiou financeiramente 27 projetos (em 16 estados do país) de acesso e permanência de estudantes com corte raci- 
al, mas não exclusivamente estudantes negros em Universidades. Uma pluralidade de formas de acesso e de permanência, pensando em pautas muito bem diferenciadas, naquilo que tange ao que temos de permanência - focando na qualificação dessa permanência, na qualificação acadêmica.

A pauta, aparentemente, era somente mexer no vestibular, mas foi se transformando, se pluralizando. Na verdade acompanha o movimento que é anterior e, é importante pontuar também, que é o movimento de reivindicação dessa luta social antirracismo nucleada pelo que nós chamamos de Movimento Negro, que é um conjunto amplo de entidades, de iniciativas, pessoas e organizações de caráter muito diferenciado, que já vem de longa data lutando pela democratização racial do campo da educação. Começamos então a pensar numa pauta que é maior, inclusive, do que a pauta das cotas.

\section{LEI 10.639}

As pautas do Movimento Negro no campo da Educação tomam como base uma concepção ampla do que é a escolarização. Compreendem a educação como sendo o campo da formação humana, que se dá dentro de espaços escolares e também de espaços não escolares - mas, confere particular atenção para essa seara específica que é o campo da escolarização. O movimento vem, ao longo da história, colocando uma série de reivindicações, uma série de propostas.

Essa história, naquilo que é hegemônico em termos de memória do movimento, hoje indica para essas pautas um nascedouro importante: a luta a partir da Frente Negra Brasileira, na década de 1930. Parte significativa das prescrições educacionais previstas pela Lei no $10.639 / 2003$, já tinha os pontos indicados no estatuto de fundação da Frente Negra Brasileira, que é de 1931. E a FNB teve uma repercussão importante naquela década. Ela se organizou em diversos estados, chegou a se constituir como partido politico, fechado por Getúlio Vargas, com o Estado Novo, em 1937, junto com outros partidos. E lá se via o "Lutar pela inserção da História da África e da contribuição do negro para a sociedade brasileira". Isso está textualmente no estatuto da Frente Negra Brasileira.

É importante lembrar isso também porque há uma leitura hegemônica nos espaços escolares de que tais políticas, tanto a Lei no 10.639 quanto as políticas de cotas, são coisas que vêm de cima para baixo, de fora para dentro, aparecem do nada, por meio de alguns governantes, para dentro dos nossos ambientes de trabalho (escolares ou universitários). Na verdade, tais medidas são fruto de iniciativas coletivas, de movimentos sociais de lutas que, há décadas, vêm tentando tencionar o Estado e outros grupos, outros segmentos da sociedade brasileira, sobre a necessidade de construção de um país que seja mais plural, em termos de acesso ao poder e a riqueza que se aqui produz. E essa é a questão fundamental: o papel do racismo na distribuição (ou, melhor dizendo, na concentração) da riqueza e do poder em nossa sociedade.

\section{RAÇA, RACISMO E DESIGUALDADES}

Nossa leitura do papel social do racismo parte da contribuição de um autor chamado Ramon Grosfolguel, integrante de uma corrente de intelectuais latinoamericanos, chamada "grupo modernidade/colonialidade", que vem nos ajudando a repensar o papel do racismo e outros princípios de hierarquização nas nossas formações sociais. O que esse grupo coloca é a 
concepção do racismo como um sistema de dominação e poder; como sistema que tem um papel estruturante na construção da nossa sociedade.

O racismo, nesta leitura, é diferente de discriminação e de preconceito. Discriminação é um ato que confere tratamentos diferenciados a dois indivíduos, por algum tipo de critério que aquele que o pratica considera importante. Então, a discriminação é uma prática. O preconceito é um julgamento. É uma concepção sobre alguém, antes de conhecer em essência e realidade aquele alguém. $\mathrm{O}$ racismo é mais do que isso.

O racismo é um sistema de dominação global. Grosfolguel (2010) nos ajuda a pensar a importância desse sistema de dominação na estruturação do mundo que nós temos hoje. $\mathrm{O}$ autor vem apontando necessidade de reconstruímos a nossa compreensão sobre o que é o modo de produção capitalista; o que é o sistema capitalista. Ele vai dizer que o capitalismo se estrutura no mundo não apenas com um princípio de dominação e exploração, que é o principio de classe, como tradicionalmente nós aprendemos com o marxismo, mas sim, se afirma no mundo como um padrão de dominação que é multidimensional; se afirma por meio de um conjunto de eixos que são princípios de dominação, exploração e hierarquização de seres humanos. Neste sentido, o capitalismo subordina indivíduos e grupos a partir de um conjunto de hierarquias, formas de dominação e exploração política, epistêmica, econômica, espiritual, linguística, sexual, racial, etc. São 9 os princípios apontados pelo autor:

1) uma hierarquia de classe, onde o capital domina e explora uma multiplicidade de formas de trabalho;

2) uma divisão internacional do traba-
Iho entre centros e periferias;

3) um sistema inter-estatal global de organizações e instituições político-militares controlada pelos homens europeus e institucionalizada em administrações coloniais;

4) uma hierarquia étnico/racial global que privilegia os homens europeus sobre os povos não europeus;

5) uma hierarquia de gênero que privilegia os homens sobre as mulheres e o patriarcado europeu sobre outras formas de relações de gênero;

6) uma hierarquia sexual que privilegia aos heterossexuais sobre os homossexuais e as lésbicas;

7) uma hierarquia espiritual que privilegia os cristãos sobre as espiritualidades não cristãs ou não ocidentais;

8) uma hierarquia epistêmica onde se privilegiam os conhecimentos ocidentais sobre as cosmologias e conhecimentos não ocidentais, institucionalizados através do sistema global de universidades (os outros produzem folclore, mitos, mas nunca teoria ou conhecimentos;

9) uma hierarquia lingüística entre línguas européias e línguas não européias, onde na produção de conhecimentos e na comunicação se privilegia as primeiras e subalterniza as segundas como criadoras de folclore ou de culturas, mas nunca de teoria ou de conhecimentos.

O racismo então, juntamente com outros princípios de dominação, nos leva à necessidade de considerar, de reler, de produzir uma "outra" leitura do mundo que nós vivemos. A própria formação do mundo enquanto totalidade é algo que nós hegemonicamente pensamos a partir da expansão europeia, das navegações e outros eventos, que vão gradativamente vinculando diferen- 
tes partes do mundo e submetendo diferentes partes do mundo ao mesmo princípio de ordenamento que é neste movimento gestado, que nós chamamos de modernidade.

Temos que perceber o quanto neste processo é central um elemento constituinte da experiência de capitalismo no mundo: uma hierarquia étnico-racional-global que privilegia os homens europeus sobre os povos não europeus. Esse padrão é um padrão mundial: O poder é branco, ele é eurodescendente em todos os lugares do mundo. Até na África o poder é branco. A partir da colonização e após a colonização, mesmo apesar dos esforços teóricos e políticos de vários intelectuais de várias nacionalidades, e de outros intelectuais africanos, o poder na África ainda é branco.

Este padrão se materializa em cada sociedade de formas diferenciadas, com critérios de classificação diferenciados - inclusive critérios de classificação diferenciados operando dentro de uma mesma sociedade. Podemos falar, no caso brasileiro, por exemplo, de um padrão de complexo de relações raciais. Eu costumo trabalhar e utilizar a proposta de análise de um autor chamado Lívio Sansone, professor da Universidade Federal da Bahia, que diz que no Brasil temos contextos de interações nos quais o dado racial é mobilizado, enquanto princípio regulador das relações sociais e outros contextos em que ele não é mobilizado. Então você tem contextos nos quais ser negro, branco ou qualquer outra coisa não importa para a interação que se dá momentos em que o dado racial nem sequer é um elemento regulador das relações sociais; em que há integração, horizontalidade entre indivíduos de grupos raciais diferentes. A estes, ele denomina "áreas moles" das relações raciais. Porém, há outros contextos onde isso importa e é mobilizado, em que há não-integração, em que há verticali- dades, em que há desigualdades - estes configuram o que o autor denomina "áreas duras" das relações raciais. Esses contextos coexistem; se misturam no cotidiano do nosso tecido social.

Podemos dar exemplos simples, podemos imaginar inclusive como esses contextos se misturam. Se imaginarmos, por exemplo, dois amigos, um negro e um branco, que cresceram juntos, moram um do lado do outro, algo comum na nossa sociedade. Crescem, brincam juntos - o dado racial não é um dado que regula a relação entre um e outro. Imagine se em um belo dia, na época de outubro ${ }^{5}$, eles resolvem procurar um emprego num shopping qualquer, para poderem juntar um dinheiro, para poderem viajar depois no verão. Imagine que esses dois amigos saem de casa de manhã, pegam o ônibus, vamos supor que saiam daqui, do Rio Comprido, peguem o 426, que passa aqui e vai lá para o Shopping Rio Sul. Imaginem, saem daqui, de uma vila qualquer dessas e estão vivendo um contexto de interação no qual há integração, horizontalidade dessa relação entre um indivíduo branco e um negro: o dado racial não é um regulador da interação social. Na hora em que eles chegam ao shopping, para fazerem a entrevista para o emprego, eu pergunto: as chances dos dois são semelhantes de conseguirem um emprego de vendedor numa loja do Rio Sul? Não acredito que sejam. Quem passar pelas lojas do Rio Sul vai ver que a proporção de negros e brancos como vendedores não é igualitária. As chances não são semelhantes. O acesso ao emprego é um campo que Lívio Sansone chama de área dura, é uma das áreas duras das relações raciais, áreas nas quais o dado racial é um dado mobilizado,

\footnotetext{
${ }^{5}$ Para este exemplo, foram utilizados dados do contexto em que se deu a palestra, como mês, bairro, linha de ônibus, etc.
} 
regulador. Vamos supor que eles saiam de lá, voltem e peguem o ônibus de volta. Eles foram daqui para lá, viveram um contexto de integração, horizontalidade das relações raciais. Na hora do acesso ao emprego eles passam a viver um contexto marcado pela verticalidade, por desigualdade nas relações raciais. Voltam para o ônibus, começam a conversar de novo, voltam a viver o contexto de integração marcado pela horizontalidade das relações raciais. Vamos supor que a polícia entre no ônibus. Saindo do Túnel Santa Bárbara a polícia adentra no ônibus. Eu pergunto: as chances de abordagem policial são semelhantes para os dois na nossa sociedade? Não são. Eles voltam a viver, no contato com a polícia, um contexto marcado pela desigualdade racial.

O nosso tecido social é marcado por uma pluralidade, pela coexistência de contextos em que há integração, horizontalidade, igualdade nas relações raciais e, simultaneamente contextos em que não há integração, contextos em que há verticalidade, desigualdade nas relações raciais. É isso que nos permite, ao mesmo tempo, achar que a nossa sociedade é uma sociedade racialmente democrática, que viveu uma democracia racial pelo fato de que há contextos em que você tem integração e horizontalidade e, não enxergarmos o fato de que há, na nossa sociedade, contextos de enorme desintegração, nos quais há verticalidade nos padrões de relações raciais. $E$ o que 0 Sansone nos aponta é que nesses contextos, em que o que está em jogo é o acesso, há desigualdade na conquista das riquezas que a sociedade produz, há verticalidade nas relações raciais. $O$ acesso ao emprego, definição de ascensão funcional no emprego, acesso à educação, acesso aos bens públicos, são campos desiguais, de um modo geral. Nesses contextos, nós temos desigualdade racial. São áreas duras nas relações raciais.
Isso resulta numa sociedade em que o dado racial é um dado estruturante, apesar de ter contextos de integração, de igualdade e horizontalidade. Portanto, o racismo aparece como sistema de dominação que é central da nossa experiência social, assim como outros sistemas que Grosfoguel aponta.

Essa pluralidade é de uma complexidade tão grande que coexistem, inclusive, diferentes sistemas classificatórios. Vou me ater aqui especificamente ao dado das relações raciais. Vou me centrar nisso, não vou falar dos outros princípios de hierarquização que nos mostra Grosfoguel. Coexistem na nossa sociedade, diferentes sistemas de classificação racial. Pensemos num outro exemplo, no contexto da favela da Rocinha, onde eu dava aulas. No Pré-Vestibular para Negros e Carentes da Rocinha todos afirmavam: "Renato, aqui é uma favela com maioria nordestina. O racismo aqui é pesado, o pessoal não gosta de preto, de negro. Nós temos que mudar o nome desse curso, porque os alunos não vêm, porque dizem que é para negro e o pessoal não gosta disso, não sei como fazer". Todos os meus alunos e professores, que eram da Rocinha, me diziam que dentro das relações sociais e raciais na Rocinha, existe um padrão de discriminação, baseado, no que podemos inserir, num sistema classificatório que polariza "brancos" (ou, aqueles que se colocam na posição de brancos) e "não-brancos". E aí podemos ver o dado da complexidade. $O$ individuo que é nordestino ou descendente de nordestino, que está ali na Rocinha e que não gosta de negros, conforme esses relatos que eu recebi, se relaciona operando com esse critério; com essa estrutura classificatória, se posicionando como "branco" no contexto da Rocinha, e discriminando os "não-brancos" - no caso, os negros. Esse mesmo indivíduo, se for para o Leblon, lá poderá ser considerado pejorativamente 
como "paraíba", denominação que denota o preconceito pela origem regional, algo também presente no Brasil. No Leblon, portanto, ele vai ser o "não branco" do sistema classificatório. Os outros brancos do Leblon não vão querer ou não vão gostar de se misturar com ele. Tal exemplo nos coloca (i) a existência de dois padrões classificatórios, um na Rocinha e outro no Leblon, e (ii) que um mesmo indivíduo pode ser classificado de formas diferentes em cada contexto.

Esse é o dado de complexidade das nossas relações sociais. Essa classificação é fundamental para constituir uma sociedade de padrão hierárquico - e isso é tristemente importante para o Brasil. Não podemos esquecer, que estamos tratando do Brasil, de uma sociedade que deu talvez o maior salto econômico do planeta nos últimos cem anos e que, mesmo tendo dado esse salto econômico, é um dos países que ainda hoje tem das piores distribuições de riqueza do mundo. Ainda é um dos países que tem os piores padrões de concentração de riqueza, mesmo com as políticas de distribuição de renda que vêm sendo implementadas há uma década.

Como é que se dá um salto econômico desses e se mantém com um padrão de concentração da riqueza? Você precisa, necessariamente, operar no tecido social com um conjunto de princípios que alijem do acesso à riqueza parte significativa da população. Esse é o fundamento, esse é o principio que mantém a nossa sociedade como sendo uma sociedade que tem o racismo como elemento estruturante. Isso é fundamental para o nosso modelo de capitalismo: dependente, periférico, subordinado e, segundo Chico de Oliveira, baseado no que ele chama de "padrão de acumulação de base pobre".

Nós estamos falando, portanto, de um sistema que é complexo, multidimensio- nal, e cujo combate, evidentemente, vai ensejar uma pluralidade de formas de ação. Não se transforma uma realidade tão complexa de uma hora para outra, nem sem algum tipo de dor, algum tipo de esforço por parte dos diferentes segmentos que compõem a sociedade. É isso que o Movimento Negro vem tentando estruturar e vem, de algum tempo para cá, operando com diálogo direto, por meio do Estado, para a construção do que vem sendo chamado, no campo das políticas públicas, de "ações afirmativas". Esse é o foco fundamental de ação do Movimento Negro na sua luta antirracismo nas últimas décadas.

\section{AÇões AfIRmativas}

Como o racismo consiste num sistema de dominação complexo e multidimensional, os focos de combate têm que ser diversos. Tratamos anteriormente da distinção entre preconceito e discriminação, e precisamos retomá-los agora. O primeiro, o preconceito, diz respeito a uma visão que alguém tem de outrem, que não conhece, ou seja, um acervo de informações (no caso, pejorativas) imaginadas a partir de estereótipos (lastreados em distintas fontes de informações socialmente produzidas que tem exatamente a função de hierarquizar indivíduos e grupos). Preconceito é, portanto, parte (e não apenas fruto) de visões de mundo - que são também visões de si, e visões do "outro". Já a discriminação remete ao campo das práticas, às atitudes que, conscientemente ou não, prejudicam indivíduos ou grupos.

Historicamente, estes são os dois focos centrais de combate ao racismo: combater as práticas que o consubstanciam (discriminação) e as visões de mundo (visões de si e visões do outro) que constroem e autorizam a hierarquização de indivíduos e 
grupos com base em raça. Chamamos aqui atenção para um movimento recente, de alargamento e deslocamento do foco do movimento negro na sua luta contra o racismo: das práticas que consubstanciam o racismo, tem-se buscado também focar para os seus impactos sociais.

Se tomarmos a década de 1980, por exemplo, o foco central de combate e intervenção do Movimento Negro eram as práticas que materializavam o racismo. Daí frutificou, por exemplo, a Lei Caó (Lei no 7.437, de 20 de dezembro de 1985), ratificada pela Constituição de 1988, que criminaliza as práticas de discriminação com base racial.

Entretanto, a efetividade disso vem sendo amplamente questionada - há um conjunto de mecanismos de neutralização da eficácia dessa medida de combate ao racismo focada nas práticas, e na maioria das situações ou as denúncias são descaracterizadas como racismo, ou sequer são feitas. Entendemos e, nesse quesito, o movimento vem pluralizando os seus focos, que existe uma série de situações em que nós identificamos efeitos do racismo, mas não conseguimos reconstituir a cadeia de práticas que gerou aqueles efeitos.

Vamos dar um exemplo: dados do DATASUS indicam que temos uma proporção muito maior de mortalidade materna entre mulheres negras do que de mulheres brancas. Existe aí uma desigualdade racial, medida estatisticamente, com todas as ponderações de renda, de escolaridade, etc. Observando nos bolsões de pobreza, onde há mulheres brancas e negras igualmente pobres, com atendimento na mesma rede hospitalar, identificamos desigualdades raciais. Por que as mulheres negras morrem mais - no processo de gestação ou em trabalho de parto? Podemos fazer suposições, inferir, cogitar várias hipóteses: os médicos matam? Os anestesistas dão uma dose me- nor de anestesia, achando que aquela muIher aguenta mais a dor ou se comovem menos com a dor daquela negra do que de outra mulher? Enfim, o fato é que não é possível reconstituir a cadeia de práticas que leva a essa desproporção em termos de óbitos de mulheres brancas e negras. Também não é intenção colocar todo mundo na cadeia. Nesse caso deve-se intervir em que? Nas práticas? Buscar os autores das práticas e penalizá-los judicialmente?

O Movimento Negro vem propondo ir ao campo e debater, discutir, pensar em medidas para intervir nos efeitos sociais, nos impactos sociais do racismo, que chamamos de desigualdades raciais. Estamos, aqui, chamando a atenção para as desigualdades que são impactos sociais da operação de uma ordem social baseada nesse sistema de dominação chamado racismo. Nem sempre se consegue reconstituir as cadeias de práticas que produzem desigualdades. Mas, o fato de não conseguir constituir as cadeias de práticas, não pode causar paralisia, não deve levar à opção de não fazer nada e esperar que a natureza vá resolver um problema social - há que se fazer sempre algo.

Por exemplo, acesso à escolarização: é um aspecto onde há desigualdades raciais, patentes em níveis de repetência, evasão, etc. Ao entrarmos numa escola pública de periferia, observamos ali frontalmente os impactos sociais de uma ordem social racializada dentro da escola. É só entrarmos numa escola. Se pegarmos uma turma de $1^{0}$ ano do Ensino Fundamental, vemos uma composição racial: alunos brancos, negros, todos ali. Do $1^{\circ}$ ao $8^{\circ}$ ano a escola vai dividindo os alunos pelo desempenho e, ao entrarmos numa turma de 90 ano, já vemos mudanças na composição racial das turmas: na 901, vemos uma composição racial; na 908, 909 e 910, vemos outra composição racial: a predominância de negros (e, princi- 
palmente, meninos). Se formos nas turmas de EJA, nas quais o descompasso entre idade e série é mais forte ainda, veremos a predominância absoluta, em qualquer turma, de população negra.

Não estamos falando de brancos ricos e negros pobres, nosso exemplo fala de brancos e negros submetidos a um mesmo contexto socioeconômico, dentro de uma mesma posição socioeconômica na nossa sociedade, brasileiros pobres do mesmo jeito e, há, naquela situação, a reprodução de uma ordem social racializada. 0 que fazer para combater o racismo nesse contexto? Vamos colocar os professores e a direção na cadeia? São os professores e professoras que discriminam e, portanto, vamos prendê-los? Não. O foco do combate ao racismo que o Movimento Negro vem propondo nesta situação não é na criminalização das práticas, mas sim, nos efeitos. Precisa-se fazer algo; combater esses efeitos. Que políticas nós vamos adotar?

A definição de um foco nos efeitos sociais do racismo permite a proposição de medidas mesmo em situações onde é difícil até mesmo identificar as práticas discriminatórias. Há situações em que as práticas são aparentemente neutras, mas, como incidem sobre trajetórias já marcadas pelo racismo, elas acabam tendo impacto desproporcional, causando desvantagens ao grupo desfavorecido. As cotas nas universidades são exemplo disso, pois a reserva de vagas incide diretamente sobre a desigualdade racial no acesso à educação superior. O vestibular é, aparentemente, um processo seletivo neutro, no qual o pertencimento racial de cada candidato nada tem a ver com a seleção. Entretanto, o que se verificava historicamente era uma representação desproporcional da população negra nos bancos universitários e, se há uma desigualdade racial, temos que fazer alguma coisa. Temos que colocar o foco ali. Temos que colocar o foco onde essa desigualdade se produz? Também. Mas, até resolver, até que se mude o conjunto de cadeias de práticas que nós não conseguimos reconstituir, há que se acelerar o processo de correção dessas desigualdades, onde quer que elas sejam identificadas.

Desse modo, temos que praticar políticas como reserva de vagas, cotas de participação ou outra que se pratica muito nos Estados Unidos, denominada de recrutamento ativo. Dizem: queremos diversidade aqui. Para ter diversidade, há que haver brancos, negros, hispânicos, orientais, etc. De onde vêm estas pessoas? Vamos procurar o talento onde ele está. Então algumas instituições (empresas, etc.) vão a comunidades negras, procuram e oferecem bolsas para os alunos que eles acham que têm melhores condições de se adaptar àquele ambiente. Ou seja, buscam-se os talentos onde eles estão. É o contrário do que nós fazemos aqui, sobretudo nas nossas universidades. Nosso recrutamento é passivo. Lançamos um edital e o "mercado" (ou, o tecido social) se encarrega de dizer, de determinar quem é que vai procurar nossa vaga ou não.

Essa postura passiva das nossas universidades, na verdade, acaba colaborando para a produção das desigualdades. Pensase: "a universidade não tem nada a ver com isso". Se vêm mais brancos procurar, mais deles fazem o vestibular para medicina, a instituição não tem nada a ver com isso. É o recrutamento passivo. $O$ recrutamento ativo necessita que você busque o talento onde ele se encontra e assuma, às vezes, o ônus pela formação adicional que esse talento precisa ter.

Estas são algumas estratégias de intervenção em efeitos, em impactos sociais do racismo, ao invés de buscar criminalizar as práticas discriminatórias. Um terceiro 
foco é voltar-se aos fundamentos, nas bases de reprodução do próprio racismo enquanto ideologia, conjunto de crenças.

A reprodução do racismo se vale de processos de produção de uma leitura de mundo (leitura de si, "leitura do outro") que permite (i) a diferenciação e (ii) a hierarquização dos seres humanos. Definir elementos corpóreos que constituam um princípio classificatório de seres humanos, o princípio da "raça", não é algo simples. A Biologia (e as ciências biomédicas) durante muito tempo ofereceu hegemonicamente um lastro para esta operação classificatória, mas atualmente o que é hegemônico é a não sustentação - sobretudo através das pesquisas em genética baseadas em códigos de DNA. Segundo estas (ver Pena, 2005), dois indivíduos de "grupos raciais" distintos (p. ex., um branco e outro negro) podem ter mais proximidade de códigos de DNA que com outros indivíduos de seus respectivos grupos. Entretanto, no âmbito das relações sociais cotidianas, independente do que esta ciência diz, permanece a operação da classificação de seres humanos com base no critério racial. Tal critério, que parte da valorização de alguns traços corpóreos (p. ex., cor da pele, cabelo, traços do rosto) como base para diferenciação, é absolutamente artificial, socialmente construído e historicamente inserido. Chega a soar estranho e mesmo absurdo para nós imaginarmos a diferenciação de pessoas pelo tamanho das orelhas, entretanto, convivemos com a diferenciação a partir da cor da pele, por exemplo. Por que convivemos com determinados critérios de diferenciação? Como eles se reproduzem socialmente?

Há, no processo de formação humana, a introjeção de informações que fazem com que as pessoas julguem as outras de formas diferenciadas, a partir de critérios socialmente construídos, artificiais, inventa- dos. Uma frase que é bastante comum dentro do Movimento Negro é ninguém nasce racista, ninguém traz o racismo na sua bagagem genética. Se há racismo, se há discriminação, é porque há aprendizados dele, aprendizados de leituras que fazem as pessoas acharem que esse é mais inteligente do que aquele, que esse é mais apto para determinadas coisas do que aquele, que esse é mais bonito do que aquele, que esse tem mais vocação do que aquele para algo, e assim em diante. Estamos falando de aprendizados que se dão nos diferentes campos de sociabilização, e que devem ser combatidos enquanto visões de mundo. Então, coloca-se o foco nos fundamentos ideológicos do racismo, com base na hipótese de que, mudando mentalidades, é possível mudar atitudes.

Portanto, estamos falando de três focos das políticas de combate ao racismo: nas práticas, nos impactos sociais, e nos fundamentos. Como esses diferentes focos se materializam em termos de ação, em termos de política?

O Brasil vem construindo hoje uma experiência bastante ampla de políticas de combate ao racismo. Temos chamado essas políticas de ações afirmativas. Estamos falando aqui de três focos diferentes, possíveis de combate ao racismo. Cada um desses focos pode ensejar uma ação ou um conjunto de ações. Não existe problema social que você resolva com um toque de mágica. Qualquer problema social envolve complexidade, e uma questão ordem da complexidade dessa que nós estamos falando, requer um pacote bastante ampliado e diverso de ações.

A experiência de políticas de combate ao racismo que o Brasil vem construindo hoje é uma experiência diversificada - ainda que insuficiente diante da complexidade e amplidão da questão. Há medidas de com- 
bate ao racismo, nos seus fundamentos, nos seus efeitos, nas práticas, em diferentes campos de estruturação de políticas públicas. Temos trabalhado com uma classificação em cinco categorias de ação; cinco tipos de política. Cada tipo de política permite combater algum tipo de foco; adotar algum foco de atuação e ter impactos, ter efeitos, em função de objetivos diferentes. TrabaIhamos com as seguintes categorias:

1) Políticas Repressivas - caracterizadas pelo recurso ao aparato jurídico-legal, são focadas em práticas identificáveis de discriminação - seja ela manifesta ou presumida. A partir da Constituição Federal de 1988 estas políticas tiveram grande importância como instrumento de fortalecimento do debate sobre a discriminação, primeiramente com (i) a acusação e prisão (criminalização das práticas de discriminação intencional ou manifesta) e também com (ii) a criação de delegacias especializadas em crimes raciais e serviços de denúncia como SOS Racismo. Tais ações apresentaram, entretanto, resultados que não expressam a dinâmica da discriminação em nossa sociedade, sobretudo, segundo Gomes, pela necessidade do acusado comprovar a motivação racial (recai sobre ele o ônus da prova de intenção), e pela resistência da polícia e do judiciário em dar encaminhamento a esses inquéritos e processos (o que é uma forma de racismo institucional). Mais recentemente, novas experiências de ações vêm sendo desenvolvidas na esfera jurídica, das quais destacamos (iii) litigância, defesa de direitos coletivos, sobretudo através de ações civis públicas e (iv) a proposição de termos de ajustamento de conduta, instrumentos de promoção de comportamentos. Estas novas medidas exemplificam a mudança de foco do "controle coativo" ao "controle persuasivo" nas chamadas políticas de cunho repressivo;
2) Políticas de Valorização - caracterizadas pela busca da ampliação do reconhecimento, do reforço da identidade, e da intervenção antirracista na construção de subjetividades e visões de mundo, de si e do outro. A principal é a Lei 10.639 , talvez a iniciativa que mais mobiliza o ativismo antirracista atualmente em sua implementação, mas, outras iniciativas nas áreas de comunicação (campanhas e iniciativas na mídia), patrimônio histórico e cultural (com tombamentos, como o da Serra da Barriga onde se localizava Palmares, e a criação de museus que valorizam a cultura e a história negra) e a criação em diversos municípios e estados do feriado do Dia da Consciência Negra em 20 de novembro também são iniciativas importantes no campo das políticas de valorização.

Estas são fundamentais para nós. São as políticas que tentam equilibrar o reconhecimento, equilibrar a representação e o reconhecimento dos diferentes indivíduos e grupos que compõem a nossa sociedade. Então vamos tentar valorizar aqueles grupos que são socialmente desfavorecidos. Como é que se provocam os equilíbrios nas representações dos diferentes indivíduos e grupos da sociedade? Através de políticas de valorização. Amplia-se o reconhecimento, reforçam-se e atribuem-se significações positivas às identidades que são desqualificadas na nossa sociedade e constroem-se tentativas de reconstruir subjetividades em prol da igualdade e da formação de mentalidades que pensem igualdades.

A lei no 10.639 é o principal foco, mas, precisamos pensar sua articulação com a política de patrimônio histórico e cultural: o feriado do dia da Consciência Negra em 20 de novembro, por exemplo; as políticas de regulação fundiária e de reconhecimento territorial quilombolas. Estamos conquistando a terra para os quilombos, mas não de- 
vemos pensar que é só dar a terra para os quilombolas. Ao reconhecer a comunidade quilombola, estamos reconstruindo, ressignificando a nossa própria história. Aprendi e tive aulas de História na minha formação escolar que diziam que "os negros eram escravos", e não, "escravizados", indivíduos e grupos sequestrados e privados de sua condição de liberdade. E mais, ouvimos que os negros foram escravizados, porque eles se adaptavam à escravidão. Ainda ouvíamos que o índio não aceitava a escravidão, pois o índio fugia e que o índio não trabalhava, enquanto o negro se adaptava. Era a mesma coisa que dizer: o negro aceitava a escravidão. Ninguém quer se identificar como herdeiro daquele que aceitou, passivamente, uma violência desse tipo. A emergência das comunidades quilombolas, o reconhecimento a elas, é algo que ressignifica o nosso passado, mesmo que não tenhamos sido quilombolas, mesmo não estando numa comunidade. Isso reequilibra o nosso papel histórico na construção da nossa sociedade. Também é política de reconhecimento. Há ainda as políticas de mídia, como campanhas como aquela: "onde você guarda o seu racismo?" Enfim, uma série de políticas vem tentando equilibrar as representações dos diferentes grupos que compõem a nossa nação;

3) Políticas de Combate Direto a Desigualdades - medidas que buscam a reversão direta de impactos sociais do racismo, objetivando a igualdade em resultados estatisticamente comprovados. Campos como mercado de trabalho, educação, saúde, entre outros em que estudos e estatísticas vêm sendo produzidos evidenciando desigualdades raciais, vão cada vez mais sendo provocados por propostas para sua reversão.

As cotas de reserva de vagas no ensino superior (e outras correlatas com o mesmo escopo, o acesso à universidade) são as mais famosas e polêmicas, mas há uma série de outras políticas com este caráter. O fortalecimento de indivíduos ou grupos desfavorecidos era o que o Movimento Negro e outros militantes faziam (e ainda fazem) no Pré-Vestibular para Negros e Carentes. Eram(são) cursos para fortalecer, para qualificar pessoas do grupo socialmente desfavorecido. É outra maneira de se tentar combater diretamente as desigualdades, no foco de origem do processo de produção das desigualdades. Abrir este leque de formas de combate direto às desigualdades, em diferentes campos, é fundamental;

4) Políticas de Ampliação de Espaços de Interlocução/Representatividade Política dizem respeito à criação de aparelhos institucionais voltados para a temática racial, com objetivos de ampliar a participação da comunidade negra junto a setores do Estado (em âmbito federal, estadual ou municipal) ou propor, assessorar, implementar e avaliar políticas públicas. A SEPPIR, o CNPIR (Conselho Nacional de Promoção da Igualdade Racial) e o Sistema PIR são marcos deste tipo de política, mas registra-se um histórico que vem desde a década de 1980 de criação de conselhos e órgãos de assessoria em alguns estados e municípios.

A criação de marcos institucionais instaura um novo diálogo entre Estado e a Sociedade Civil, com o reconhecimento público não apenas das pautas trazidas pelo movimento social, mas também, de seu expertise na formulação, execução e avaliação de políticas públicas. É fundamental dialogar com as entidades do movimento social que levem essa bandeira; aprender com essas entidades; legitimar os saberes acumulados dessas entidades sobre o problema social do qual nós estamos falando. Então, criar canais de diálogo e participação como o Estado vem fazendo em algumas esferas (SEPPIR, Conselhos, etc) para dialo- 
gar com a comunidade, é uma estratégia central, pois abre possibilidades para a proposição de novas iniciativas;

5) Políticas de Combate ao Racismo Institucional - tem como foco o comportamento de instituições nas quais a reprodução de estereótipos, comportamentos e leituras que naturalizam o racismo, as desigualdades e a discriminação nas relações raciais acabam por afetar o acesso a oportunidades iguais e a possibilidade de usufruto equânime. 0 racismo institucional é definido como "o fracasso coletivo das organizações e instituições em promover um serviço profissional e adequado às pessoas devido à sua cor, cultura, origem racial ou étnica" ${ }^{\prime 1}$, o que é fundamental para a dinâmica de reprodução do racismo sobretudo em campos como saúde, educação, direito e segurança pública, entre outros.

O combate ao racismo institucional é outra frente fundamental na qual temos pouco agido. Temos feito pouco nesses dez anos de implementação de políticas de cotas na Universidade. Algumas universidades trabalharam processos formativos para professores e técnicos, servidores administrativos, que passam a lidar com o aluno que tem o ingresso na universidade num processo que não é o formato histórico daquele meio. Portanto, esse aluno tende a ser discriminado ali dentro, tende a sofrer a atribuição de uma carga pejorativa. Há que se mudar essa mentalidade. E mudar a mentalidade é combater o racismo institucional, a forma como essa instituição se comporta ao dar tratamento diferenciado para esses indivíduos. Trabalhar processos formativos para os quadros internos é fundamental. A implementação das cotas sem que isso ocorra coloca aquele aluno ainda mais exposto à discriminação no ambiente institucional, e isso pode ter consequências diversificadas. Os alunos podem evadir, ampliando taxas de evasão, diminuir os desempenhos escolares, ou, se aglutinar como forma de defesa, se autossegregar e se constituir em grupo que radicaliza contra aqueles que consideram imprimir-lhes algum tipo de violência. Então, podem ocorrer padrões de reações diferentes.

Então, é fundamental haver campanhas, coletas e difusão de informação sobre o quesito cor e outras medidas. A busca e produção de dados sobre o quesito cor na instituição é ação que vem sendo proposta para elucidar a presença do racismo nas instituições. Nós temos o levantamento de quantos professores negros há nas universidades, por exemplo? Não vemos isso circulando. $\mathrm{E}$, é fato: docentes podem passar toda a sua trajetória profissional dentro da universidade (até 30, 35 anos de trabalho) sem jamais se relacionar com um colega negro no seu departamento. Indo a reuniões de departamento, colegiados monocromáticos. Este docente pode até experimentar no ambiente universitário relações interraciais, se p. ex. o segurança for negro. Mas, este não é o tipo de interação marcada pela horizontalidade; não é uma interação entre iguais na vivência da instituição. Então, coletar informação sobre as instituições pode fazer com que as pessoas passem a ver aquilo que a ideologia da democracia racial nos impede de ver, nos cega, nos blinda, que é a reprodução de uma ordem social racializada, nos ambientes em que nós vivemos. Portanto, é fundamental isso, como instrumento de combate ao racismo institucional.

Poderíamos tratar mais das pautas no campo da educação, mas ao longo destas notas abordamos esse conjunto de ações que hoje vêm retendo a maior parte das atenções dos indivíduos e grupos que lutam pelo combate ao racismo. E é importante que olhemos essas agendas como 
uma pauta unificada. Setores contrários dizem que o Movimento Negro só quer saber de cotas. Quando vamos aos fóruns do Movimento, o que mais tem ocupado as pessoas é o trabalho pela implementação da Lei no 10.639, que é uma lei que tenta transformar a escola em espaço de produção da igualdade. Então, dizer que o movimento só quer saber de cotas e não quer melhorar o ensino básico, é mentira - uma mentira que se reproduz. $\mathrm{E}$, a agenda é muito mais extensa.

\section{REFERÊNCIAS BIBLIOGRÁFICAS:}

GROSFOGUEL, Rámon. Para descolonizar os estudos de economia política e os estudos pós-coloniais: Transmodernidade, pensamento de fronteira e colonialidade global. In: Santos, Boaventura de Sousa; Meneses, Maria Paula (Orgs.). Epistemologias do Sul. São Paulo: Cortez, 2010.

OLIVEIRA, Chico de. "O Estado e o urbano no Brasil". Revista Espaço \& Debates, n. 6, 1982, p. 36-54.

PENA, Sérgio. "Razões para banir o conceito de raça da medicina brasileira". História, Ciências, Saúde - Manguinhos, v. 12, n. 1, p. 321-46, maio-ago. 2005.

SANSONE, Lívio. "Nem somente preto ou negro: o sistema de classificação racial no Brasil que muda". Afro-Ásia, n. 18, 1996, Salvador, pp. 165-188.

\footnotetext{
${ }^{1}$ Definição extraída da página eletrônica do programa: www.combateaoracismoinstitucional.com.
} 